\title{
The Big Problem of Large Bills: The Bank of Amsterdam and the Origins of Central Banking*
}

\author{
Stephen Quinn \\ Department of Economics \\ Texas Christian University \\ s.quinn@tcu.edu
}

\author{
William Roberds \\ Research Department \\ Federal Reserve Bank of Atlanta \\ william.roberds@atl.frb.org
}

January 25, 2005

\begin{abstract}
A bstract
This paper outlines a model of the first true central bank, the Bank of Amsterdam, founded in 1609. Employing a variant of the Freeman (1996) model of money and payments, we first analyze the problematic monetary situation in the Netherlands prior to the founding of the Bank. We then use the model to describe how this situation was ultimately remedied through the Bank's creation of a stable medium for the settlement of commercial obligations.
\end{abstract}

${ }^{*}$ Preliminary and incomplete. 


\section{Introduction}

During the Renaissance, many Mediterranean cities created financial entities known as exchange banks. The purpose of these banks was to insulate their host cities' commercial payments systems from the vagaries of fractional reserve banking. ${ }^{1}$ Exchange banks had full reserves and did not issue banknotes. Commercial debts could be settled by the transfer of deposits between bank accounts without the risk of the bank failing. Coins held in the bank were secure against theft and did not have to be repeatedly assayed.

In 1609, Amsterdam opened the first exchange bank in northern Europe. The principal purpose of the Bank of Amsterdam, however, was not to protect against the failure of private banks, but, instead, to discourage the circulation of debased coins (van Dillen 1934, 80). ${ }^{2}$ Our argument is that the Bank of Amsterdam, called the Wisselbank in Dutch, was ultimately successful in its goal. As a consequence, the Dutch Republic was able to maintain a stable system of coinage for roughly 150 years, and Wisselbank money became the foundation of European commerce and finance. ${ }^{3}$ As late as 1776, Adam Smith in The Wealth of Nations praised the money of the Wisselbank for "its intrinsic superiority to currency."

At the turn of the 17th century, Amsterdam suffered from a debasement problem because of the interactions between coins and commercial credit. As a small, open economy, the Dutch Republic was awash in a variety of coins, so local officials repeatedly set ordinances that specified "legal" values for coins, i.e., the value of specific coins in the settlement of debts. The goal was to reduce transaction costs and uncertainty, and, by 1600, these ordinances covered nearly 800 foreign coins (Dehing and 't Hart 1997: 40). The ordinances, however, created an incentive for mints to debase coins, for the debased coins could be brought to Amsterdam and passed to creditors at ordinance prices. Creditors suffered because commercial credits were repaid with lighter-than-expected coins. And when credit suffered, Amsterdam suffered.

To model the cause of debasement in the Dutch case, we draw on theoretical frameworks developed in Sargent and Smith (1997), Sargent and Velde

\footnotetext{
${ }^{1}$ The first exchange bank was in Barcelona in 1401, followed by Genoa in 1407, Valencia in 1408 and, much later, Venice in 1587. See Mueller (1997, 116-8).

${ }^{2}$ Roughly simultaneously with the founding of the Wisselbank, Amsterdam did attempt to outlaw private banks. This attempt was ultimately unsuccessful. See Dehing and 't Hart $(1997,46)$.

${ }^{3}$ One measure of the Wisselbank's success was its ability to inspire the creation of similar institutions across northern Europe (Delft, Hamburg, Middelburg, Nuremberg, Rotterdam, and Stockholm).
} 
(2002), and Sussman and Zeira (2003). ${ }^{4}$ What is new in our setup, however, is that the impetus for debasement does not arise from physical deterioration of coins (Sargent-Smith), tensions between large and small coins (SargentVelde), nor from asymmetric information about the precious metal content of coinage (Sussman-Zeira). Instead, debasement arises as a form of taxation that can be applied to commercial credit. To link debasement to commercial credit, we introduce a Freeman (1996)-style overlapping-generations model with the feature that coins used to settle debts can be debased after a debt is created.

In our approach, incentives to debase arise because mints and debtors share the surplus that a debasement extracts from creditors. Moreover, the model demonstrates that incentives to debase can occur, even when the value of full-weight coins are free to rise in spot transactions because, again, the ordinances allow creditors to be taxed. Debasement can also cause inflation because the local economy is tied to the world economy. Following a debasement, goods producers with export opportunities will demand more light coins so as to get an amount of silver similar to what the rest of the world offers for their goods. The combination of inflation and the loss of silver from seigniorage create an increased nominal demand for the debased coins with two important consequences: (1) the local economy must export goods to gain additional silver, and (2) the new coins will be of the debased variety, so a sort of "Gresham's Law" effect arises. ${ }^{5}$

Our model then shows how an institution such as the Wisselbank discourages debasement through a modification of the legal concept of money. The value of Wisselbank money was tied to the legal value of "heavy" coins, and the value of a deposited coin is assessed, to a first approximation, by the intrinsic content of deposited coin relative to the bank's reference coin. ${ }^{6}$ To compel participation, all commercial credit transactions must be settled via the bank. The result for creditors is that a stable unit of account for debt settlement is retained while the silver content of the coins used for settlement is also guaranteed. In turn, the incentive to debase is blunted because debtors now bear the costs of the debasement when they deposit light coins at the Wisselbank.

With the end of debasement, the Wisselbank deposits began to resemble what is now called outside money. To avoid Wisselbank fees, creditors began

\footnotetext{
${ }^{4}$ Velde and Weber (2000) employ a related framework in their analysis of bimetallic standards.

${ }^{5}$ We use the term "Gresham's Law" with some caution, as there are other features of our model that are inconsistent with this law as it is often interpreted.

${ }^{6}$ The "weight" of coins is defined more precisely below.
} 
to sell ownership of deposits to debtors in exchange for circulating coinage. Money on the books of in the Wisselbank came to be called money in banco, money outside the bank were called current money, and the market exchange rate between them was described by the agio, or premium on banco funds. With no debasement and a robust market exchanging banco and current money, bank coins were rarely withdrawn. The final regulatory change was to disallow the withdrawals altogether. At this point Wisselbank deposits became an outside money because the bank no longer faced any liability of conversion. And as an outside money, debasement of coins circulating current money could be instantly sterilized by a rise the agio.

\section{Historical Background}

Today, the commonplace notion of "money" incorporates at least three distinct concepts: a unit of account, inside money, and outside money. In ordinary commerce these are often taken as synonymous: a dollar bill is thought of as having the same value as a dollar in the bank, and both of these are treated as "one dollar" in everyday financial calculations. To people living in Early Modern Europe, however, the distinctions between these concepts were readily apparent because of the instability of multi-coin, commoditybased systems. Monetary systems were routinely formed with a standard coin as the unit of account, but frequently some shock drove the standard coin out of circulation while leaving the unit of account in continued use. ${ }^{7}$

Units of account outlasted their coin because debt contracts continued to be denominated in the relevant unit of account. In the Dutch case, the 1543 silver florin of Charles $\mathrm{V}$ was a coin set to be worth twenty stuiver coins, but the debasement of stuivers drove florins out of circulation (see Dehing and 't Hart 1997, 38; van Dillen 1934, 82). By the founding of the Wisselbank in 1609, the unit of account in most of the Dutch Republic remained the florin (also called the gulden or guilder) despite there no longer being florin coins. The value of coins and financial obligations were all defined in terms of the florin.

The analog of outside money was coin. Coin circulating within the Republic consisted of both domestic and foreign coins. Most circulating coins were given lawful status, i.e., they were assigned a specific value in terms of florins, by a minting ordinance. ${ }^{8}$ In this sense, the intent of the minting

\footnotetext{
${ }^{7}$ For the example, the French écu of 1577 came to cease circulating yet operated as a unit of account for 25 years (Sargent and Velde 2002, 211).

${ }^{8}$ Not all foreign coins were given legal status. Coins with very low fine metal content,
} 
ordinance was that coins should circulate by "tale" and not by the weight of the precious metal contained in each coin. However, the intrinsic value of the coins placed some specific limits on the government's ability to set the relative values of the various coins in circulation. When these limits were surpassed, as often occurred in the early years of the Republic, the heavier coins would disappear from a circulation, and a new minting ordinance would be passed in response.

Minting standards were quite lax in the early years of the Republic. The Union of Utrecht in 1579 sought to end competitive debasements between provinces, but the confederate structure of the Republic allowed eight provincial mints (the province of Holland had two) and six municipal mints to produce coin within the Republic's boundaries (Dehing and 't Hart, 1997, 38). Moreover, numerous mints produced small coins for local transactions, so the total number of mints in the Republic was approximately forty (Korthals Altes 2001, 41). Mints were often run with an eye more towards the production of seigniorage for their respective governments, than towards maintaining a stable monetary standard (de Vries and van der Woude 1997, 82). The mints operated by governments outside the Republic were even less interested in, not to say openly hostile to, the idea of stable money. Coins produced at foreign mints often had a smaller metallic content, relative to their nominal value, than coins issued within the Republic. In some cases, the foreign coins were explicitly created to be lighter-weight copies of domestic coins. Contemporary accounts describe a "massive" inflow of these light coins (de Vries and van der Woude 1997: 83).

Most commercial transactions, however, did not take place in coin, but rather in privately issued claims or inside money. Generally, two types of inside money existed: bank money and bills of exchange. Bank money existed as claims on the accounts of cashiers (moneychangers who took deposits, in Dutch) operating in commercial centers such as Amsterdam. Cashiers offered a variety of payment services. Just as in modern times, a merchant could discharge a debt by transferring money in his bank account to this creditor. These transfers could circulate hand-to-hand outside of the bank by endorsement, and cashiers even issued deposit notes payable to bearer (Dehing and 't Hart, 1997, 43). Bank accounts were not reckoned in any particular coin, however, but in the unit of account, the florin.

The cashiers were legally required to exchange coins at the ratios spec-

as well as clipped and worn coins, were declared to be unlawful. However, the political structures of the Republic did not provide sufficient authority for a blanket ban on the circulation of foreign coinage. 
ified in the minting ordinance, but this requirement was not effective. In particular, two practices that deviated from this obligation were widely condemned, but apparently just as widely tolerated in the marketplace. The first practice, known as steygeringhe (roughly translatable as "overvaluation" or "gouging"), was to value coins at ratios different from those assigned in the minting ordinance, with a premium being assigned to heavier-weight coins. The second, known as bicquetteeren (roughly, "cherry-picking") consisted of holding back coins with a heavy metallic content relative to their nominal value, and paying out only lighter weight coins. The prevalence of these practices meant that money in cashiers' accounts was often de facto payable only in debased coin, or in heavy coin if the depositor was willing to pay a premium.

International payments and the bulk of commercial credit was not provided by moneychangers, but, instead, by a second type of inside money called the bill of exchange (de Vries and van der Woude 1997: 134). While there are many technical aspects of bills of exchange, for the purposes of this paper, we may think of the drawing of a bill simply as the issuance of a transferable ("negotiable") debt obligation. Although the bill might be issued or "drawn" at a remote location, it was typically payable through a cashier at a commercial center such as Amsterdam.

\subsection{The problem of debasement}

To summarize, the monetary system prevalent in the Dutch Republic at the start of the 17th century consisted of a unit of account, domestic and foreign coins, and inside money in the form of bank balances and bills of exchange. For some purposes, this system was quite passable. But it possessed a major flaw, noted by Adam Smith ([1776] 1994, 510):

[T] he currency of a small state ... can seldom consist altogether in its own coin, but must be made up, in great measure, of the coins of all the neighboring states .... . If foreign bills of exchange are paid in this currency, the uncertain value of any sum, of what is in its own nature so uncertain, must render the exchange always very much against such a state, its currency being, in all foreign states, necessarily valued even below what it is worth.

In other words, a sum payable in florins (on the accounts of a typical moneychanger) might correspond to different types of coin, each with dif- 
ferent values in international exchange, a situation hardly to the liking of parties holding bills payable in such sums.

The Republic's first line of defense against this problem was to pass a minting ordinance, giving coins specific values in terms of florins. Such efforts were generally ineffective, however, as they provided a strong incentive for local mints to further debase their coinage as a source of revenue. Merchants trading had an incentive to hold debased money, as doing so would have allowed them to discharge their trading debts with less precious metal, and to pocket some of the difference between what was required to settle their original obligation (as measured in precious metal) and what was paid back. Or, if a debt was payable through a cashier (as was typically the case), the cashier might "cherry-pick" the heavier coins and pay out the debased ones. Adam Smith ([1776] 1994, 511) summarized the difficulty of the situation:

Before 1609 the great quantity of clipt and worn foreign coin, which the extensive trade of Amsterdam brought from all parts of Europe, reduced the value of its currency about 9 per cent below that of good money fresh from the mint. ... The merchants, with plenty of currency, could not always find a sufficient quantity of good money to pay their bills of exchange; and the value of those bills, in spite of several regulations which were made to prevent it, became in a great measure uncertain.

The marketplace was willing to tolerate small differences in the weight of coins. Van Dillen $(1934,88)$ notes that the minting ordinance of 1638 valued both the cross rixdollar (minted in the Spanish Netherlands) and the rixdollar (minted in the Republic) at 2.5 florins, "though the former was of much higher degree of fineness than the latter." Often, however, an increase in the circulation of a lighter coin was fatal for a heavier one.

The short-term losers in a debasement were no doubt those who held bills of exchange payable in florins. As Adam Smith pointed out, however, the eventual losers were the Dutch merchants themselves, as creditors demanded higher and higher exchange rates on bills, in order to protect themselves from loss of purchasing power via debasements. The natural response to this situation on the part of the Republic was to revise its minting ordinances, bringing the official valuations of coins in line with market valuations. However, quite often by the time the minting ordinance was changed, all heavy coins had vanished from circulation, to be replaced by light coins. Minting ordinances were passed in 1586, 1608, 1622, 1638, and 


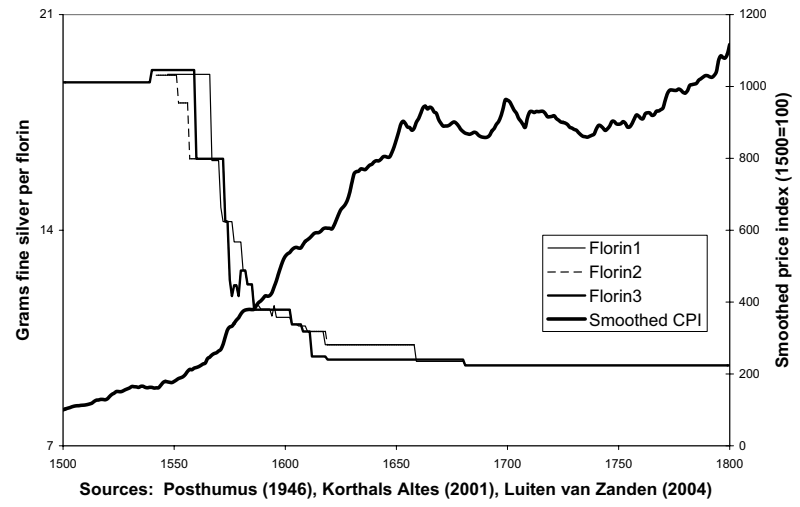

Figure 1: Money and Prices in the Northern Netherlands, 1500-1800

1659, with various revisions taking place at dates in between (Van Dillen, 1934, Korthals Altes 2001). The frequency with which these ordinances were passed was a testament to their ineffectiveness. ${ }^{9}$

Figure 1 presents time series on the silver content of the florin/guilder, as estimated by various monetary historians, and an index of nominal consumer prices. The data are for the northern Netherlands from 1500 to 1800 . Both prices and the silver content of the florin are relatively stable until around 1550. From the mid-sixteenth century until the founding of the Bank of Amsterdam (1609), the silver content of the florin falls by about one percent per year on average, while annual inflation averages about two percent (see Table 1 below).

This rate of inflation seems relatively innocuous by modern standards. Not all of the inflation seems attributable to debasement. The "silver equivalent" price (the nominal price times the silver content of the florin) increased on average by one percent annually during this period. This increase most likely reflects the increased availability of silver from the New World, as well

\footnotetext{
${ }^{9}$ The 1659 ordinance did however contribute to monetary stabilization by legally recognizing the difference between the banco and current florins (discussed below). See van Dillen $(1934,89)$.
} 
the strengthening economy of the Republic.

\begin{tabular}{|c|c|c|c|}
\hline \multicolumn{5}{|c|}{$\begin{array}{c}\text { Table 1: Average changes in money and prices } \\
\text { in the northern Netherlands, 1500-1800 }\end{array}$} \\
\hline Period & $\begin{array}{c}\text { Average annual } \\
\% \Delta \text { CPI } \\
=(1)\end{array}$ & $\begin{array}{c}\text { Average annual } \\
\text { o in silver content } \\
\text { of florin }=(2)\end{array}$ & $\begin{array}{c}\text { Average annual } \% \Delta \\
\text { in silver equivalent } \\
\text { price } \approx(1)+(2)\end{array}$ \\
\hline $1500-1549$ & 1.2 & 0.0 & 1.2 \\
\hline $1550-1608$ & 2.0 & -1.0 & 1.0 \\
\hline $1609-1658$ & 0.9 & -0.2 & 0.7 \\
\hline $1659-1779$ & 0.1 & 0.0 & 0.1 \\
\hline $1780-1800$ & 0.6 & 0.0 & 0.0 \\
\hline \multicolumn{4}{|c|}{ Source: Luiten van Zanden $(2004)$} \\
\hline
\end{tabular}

The phenomenon of debasement was nonetheless strongly condemned by contemporary observers. One reason for this dissatisfaction must have been the "lumpiness" of debasements: a coin might be stable but suddenly lose ten percent of its metallic content. Below, we explore another explanation for this dissatisfaction, which is the "double-edged" nature of inflation that arises under a commodity standard. That is, a debasement imposes costs not only on current creditors but also on participants in future credit transactions.

\subsection{An exchange bank as the (accidental) solution}

The ongoing erosion in the value of the Dutch currency led the governing council of Amsterdam to establish the Wisselbank in 1609. As emphasized by van Dillen (1934), the purpose of the founders was not to allow for the creation of any sort of central bank money, but simply to better enforce the minting ordinances. To this end, the ordinance establishing the Wisselbank put into place a number of new legal restrictions, including most importantly,

1. A requirement that all bills of exchange of 600 florins and upwards were to be payable at the Wisselbank;

2. A restriction that only lawful coins could be deposited into accounts at the Wisselbank; unlawful coins as well as bullion could be brought in to the bank, but these were to be turned over to the local mint, and the depositor credited only for the value of their precious metal (minus the customary charge for seigniorage); 
3. A restriction that the Wisselbank was bound to observe the valuations of coins as stated in the minting ordinance. (However the Wisselbank was allowed to charge a minimal withdrawal fee for certain coins.)

Together these restrictions were designed to ensure that bills were not paid in debased coin, or in cashier accounts de facto only payable in debased coin. Reflecting its purely "monetary" mission, the Wisselbank did not grant any sort of credits, but simply held the deposited coin in its vaults. Thus, a stylized balance sheet for the Wisselbank during this period would have looked like the following:

\begin{tabular}{|c|c|}
\hline Table 2: Stylized early balance sheet of the W isselbank \\
\hline Assets & Liabilities \\
\hline "Lawful" coin, & Balances held as deposits \\
(e.g., rixdollars) & \\
"Unlawful" coin and bullion & \\
(to be minted into lawful coin) & \\
\hline
\end{tabular}

During the first fifty years of its existence, the Wisselbank enjoyed some degree of success. Since Wisselbank funds were payable in coins with a relatively stable value, the pace of debasements slowed to a trickle as more and more transactions were settled in bank funds. The Wisselbank was not entirely successful, however, in its goal of "demonetizing" the lighter foreign coins, which continued to circulate. Figure 1 shows that prices continued to rise throughout the first half of the 17th century, albeit at a lower rate than before (averaging less than one percent annually from Table 1). Table 3 shows that the value of florin against the English pound at first stabilized during this period, but gradually began to erode as heavier coins were withdrawn from the bank and were replaced by lighter coin. 


\begin{tabular}{|l|c|}
\hline \multicolumn{2}{|c|}{ Table 3: A msterdam on London Exchange R ate } \\
\hline \multicolumn{2}{|c|}{ Index of the Five Year Averages, $1606-10=100$} \\
\hline $1601-05$ & 97 \\
\hline $1606-10$ & 100 \\
\hline $1611-15$ & 99 \\
\hline $1616-20$ & 100 \\
\hline $1621-25$ & 98 \\
\hline $1626-30$ & 96 \\
\hline $1631-35$ & 94 \\
\hline $1636-40$ & 95 \\
\hline $1641-45$ & 89 \\
\hline Source: Simon Hart's Five Year Averages in McCusker $(1978,55)$ \\
\hline
\end{tabular}

Throughout this period, the price of a given coin at the Wisselbank was still set by ordinance, often at a value below the actual market value of the coin as measured in florins. For example, a cross rixdollar at the Wisselbank was valued at 2.4 florins while a cross rixdollar outside of the Wisselbank was 2.5 florins (van Dillen 1934, 89-90). As a consequence, there arose two separate units of account, the current florin and the banco florin. Bills of exchange and other important financial transactions were settled in Wisselbank money and so were priced in banco florins, while spot transactions and accounts at cashiers were priced in current florins.

A market began to develop where people transferred ownership of banco deposits in exchange for current coins. Direct exchange avoided the Wisselbank's small withdrawal fee, and the exchange rate between the two was measured by the premium on bank money, known as the agio. The distinction between the two prevalent units of account was officially recognized in 1659. Table 4 summarizes the resulting changes in the monetary system of the Dutch Republic. 


\begin{tabular}{|c|c|c|c|}
\hline \multicolumn{3}{|c|}{ Table 4: M oney of the Dutch R epublic } \\
\hline \multirow{2}{*}{\begin{tabular}{c} 
Unit of account: \\
\cline { 2 - 4 }
\end{tabular}} & $\begin{array}{c}\text { Pre-Wisselbank } \\
\text { Circa 1600 }\end{array}$ & \multicolumn{2}{|c|}{$\begin{array}{c}\text { Post-Wisselbank } \\
\text { Circa 1650 }\end{array}$} \\
\cline { 2 - 4 } Coin: & Domestic coins & Current Florin & Banco Florin \\
\hline $\begin{array}{c}\text { Exchange bank } \\
\text { money: }\end{array}$ & Foreign coins & coins & $\begin{array}{c}\text { Heavy } \\
\text { coins }\end{array}$ \\
\hline Inside & Cashiers' accounts & Cashiers' & $\begin{array}{c}\text { Wisselbank } \\
\text { accounts }\end{array}$ \\
money: & Bills of exchange & accounts & exchange \\
\hline
\end{tabular}

The success of the exchange market (in coin for bank money) meant that coins were rarely withdrawn from the Wisselbank for domestic purposes. The next evolutionary step was the end of the right of withdrawal of Wisselbank deposits, which occurred sometime during the second half of the 17 th century. The exact date is unknown, and the lack of contemporary commentary suggests how inconsequential the change seemed to individual customers. From a modern perspective, however, the change meant that Wisselbank deposits became in affect an outside money because the bank faced no offsetting liability. The agio became in turn an exchange rate between coin and outside money. By transforming its deposits into outside money, the Wisselbank was able to more effectively discourage debasements and their inflationary consequences. Any drop in the silver content of current money could be offset by an increase in the value of the agio. Merchants needing to repay debts denominated in banco florins would have no incentive to hold debased coins, as these would offer little advantage in the purchase of Wisselbank funds.

A final evolutionary step in the development of the Wisselbank was the introduction of a system of receipts in 1683. A merchant could deposit bullion or coin at the Wisselbank and receive in return an advance of bank funds and a receipt. The receipt would entitle its holder a return of the bullion or coin, provided that the receipt holder returned the funds advanced, plus a very small amount of interest (e.g., one-quarter percent interest every six months for silver coin). A stylized balance sheet of the Wisselbank during its later period would look like the following: 


\begin{tabular}{|c|c|}
\hline Table 5: Stylized later balance sheet of the W issel bank \\
\hline Assets & Liabilities \\
\hline Heavy coin & Balances \\
Bullion & Receipts \\
Light coin or "current money," & \\
discounted at the agio & \\
\hline
\end{tabular}

As described by Adam Smith ([1776], 1994, 513-518), receipts would commonly circulate as form of quasi-money. Receipts and bank balances were complementary instruments. Receipts could circulate outside the Wisselbank and be redeemed for coin or bullion, while bank balances could not. Bank balances could be used to settle bills of exchange while receipts could not. Receipts and balances were freely traded in an open market, and by trading in this market, the Wisselbank was able to maintain complete control of the agio.

Figure 1 attests to the efficacy of these arrangements. By about 1650, the silver content of Dutch coins became remarkably stable, and the Dutch price level (CPI indexed to florin prices) fluctuated in a stationary way over the next century. ${ }^{10}$ The goal of encouraging commercial credit was achieved. In the words of van Dillen (1925), Amsterdam became, "the place were very nearly all the bills payable within Europe are drawn, remitted or otherwise discounted and traded (translated by de Vries and van der Woude 1997, 136)."

\section{M odel}

This section presents a model of the monetary environment of the early17th century Dutch republic, both before and after the institution of the Wisselbank. The model is adapted from Freeman (1996). ${ }^{11}$

There are three types of agents in the initial model: debtors, creditors, and cashiers. The cashiers are replaced with an exchange bank in a second version of the model.

\footnotetext{
${ }^{10}$ The only change in silver coinage between 1659 and 1839 was the introduction of the guilder in 1681 (Posthumus 1946, cviii).

${ }^{11}$ The Freeman model provides a useful vehicle for our analysis, because it allows for payment in both inside and outside money, and requires settlement of inside money transactions in outside money. This model has been employed extensively in the analysis of payment systems; see Zhou (2000) for a partial survey. Fujiki (2003) and HernandezVerme (forthcoming) have used the Freeman model to analyze economies operating under metallic standards.
} 
Debtors and creditors exist as overlapping generations of two-period lived agents. Each generation is divided into an equal number of debtors and creditors, who are distributed over a number of "islands." Debtors are born on debtor islands and creditors are born on creditor islands, and agents are distributed over islands in a symmetric way. Debtors (creditors) are endowed when young with a quantity $x(y)$ of a perishable good unique to their respective islands. There is also a central island where debts are discharged. The life histories of creditors and debtors are as follows.

Generation-t debtors wish to consume their own endowment good and the good of a creditor island in period $t$. To do this, young debtors journey to creditor islands to purchase goods from young creditors in period $t$, issuing debt (drawing bills) payable on the books of a cashier at the central island in period $t+1$ in order to make these purchases. ${ }^{12}$ They then sell some of their endowment good to old creditors in return for coin. These coins may then be subsequently deposited on the books of a cashier in order to discharge the obligation created by the drawing of the bill earlier in the period. Preferences are such that there are no double coincidences of wants: the goods of debtor island $j$ are desired by residents of a particular creditor island $k$, but residents of island $j$ are only interested in consuming goods of some other creditor island. Also, old debtors leave the central island before the arrival of the old creditors, meaning that settlement of a bill requires the services of an intermediary, i.e., a cashier.

Generation- $t$ debtors may also consume debtor goods of any type in period $t+1$. Second-period consumption is less satisfying, however, and consuming a debtor good at $t+1$ only generates utility equivalent to consuming a (small) fraction $\alpha$ of consuming a debtor good at $t$.

Formally, the representative debtor's preferences are given by

$$
V\left(d_{x t}+\alpha d_{x, t+1}^{\prime}, d_{y t}\right)
$$

where $d_{x t}$ indicates the debtor's consumption of his endowment good in period $t, d_{x, t+1}^{\prime}$ denotes consumption of a debtor good in period $t+1$, and $d_{y t}$ denotes the debtor's period- $t$ consumption of the relevant creditor good.

Generation- $t$ creditors wish to consume some their own endowment good in period $t$, and the goods of some debtor island in period $t+1$. To do this, the generation- $t$ creditors sell some of their endowment to generation- $t$ debtors in exchange for a bill payable at $t+1$, on the books of a cashier the central island. At time $t+1$, old creditors receive payments from cashiers

\footnotetext{
${ }^{12}$ Following Freeman (1996), we assume there exists an enforcement technology which guarantees that all debts will be repaid.
} 
where the old debtors have deposited their coin. The old creditors withdraw this coin and and then journey to debtor islands in order to buy the debtor goods they desire from young debtors.

The representative creditor's utility is given by

$$
U\left(c_{x, t+1}, c_{y t}\right)
$$

where $c_{y t}$ indicates the creditor's consumption of his endowment good in period $t$, and $c_{x, t+1}$ denotes the creditor's period- $t$ consumption of the relevant debtor good. Both $U$ and $V$ are assumed to be twice continuously differentiable, additively separable, and to be increasing and concave in each argument, with indifference curves that do not cross the axes.

Cashiers are single-period lived indivuals who reside on the central island. Cashiers value both types of goods and have utility given by

$$
\theta_{x t}+\theta_{y t}
$$

where $\theta_{x t}$ and $\theta_{y t}$ denote the representative cashier's time- $t$ consumption of debtor and creditor goods, respectively.

Cashiers have no endowment of goods, but are endowed with a "banking technology" that allows them to take in deposits of coin, settle obligations by transfer of accounts, and to allow for withdrawals in coin. Before describing the cashiers in more detail, we must first introduce some additional structure in the model, with three key restrictions.

Currency area and restrictions on prices. The islands in the model comprise a "currency area" (the "Low Countries") with a common unit of account ("the florin"). Prices within the Low Countries must be stated in this unit of account, and cashiers' accounts must be kept in this unit of account.

Use of debt and coins in transactions. Debts issued by young debtors must be denominated in the Low Countries' unit of account (florin) and are payable on the books of a cashier. Coins deposited with cashiers must be recognized in a minting ordinance (to be described below) but are valued at their market value. Old creditors' purchases of young debtors' goods are also made with coin. These coins are obtained by withdrawals from cashiers' accounts. The initial old creditors are endowed with stocks of at least one coin. ${ }^{13}$

\footnotetext{
${ }^{13}$ Note that this restriction rules out the use of uncoined precious metal as money, as occurs in Sargent and Wallace (1983). This is a defensible restriction given that, at the time of the founding of the Wisselbank, commercial obligations were most often settled using cashiers' accounts (payable in coin, but denominated in florins) rather than in coin itself.
} 
Mints and minting ordinances. Coins are produced by mints and a minting ordinance assigns each coin a value in terms of the native unit of account. Each coin has a fixed amount of a durable precious metal, "silver." 14 At least one mint (and possibly more) is accessible from the islands in the model, including the central island ("Amsterdam"). Each mint freely converts silver (including coins of other mints) into coin, extracting a fraction of the silver in the process. In terms of notation, let $I$ be the set of coins covered in the minting ordinance, and let $C_{t} \subseteq I$ be the set of coins circulating at the beginning of period $t$. Each coin $i \in I$ has a silver content of $b_{i}$ ounces, and the minting ordinance assigns it a value of $\underline{e}_{i}$ florins. Consistent with historical practice, we do not require that all coins circulate at their legal values. Instead, the time $t$ market florin value $e_{i t}$ of coin $i$ may exceed but cannot fall below its legal value, i.e., $e_{i t} \geq \underline{e}_{i}{ }^{15}$ The "weight" of a coin is given by the ounces of silver it contains for each florin of nominal value, i.e., the weight of coin $i$ is $b_{i} / e_{i}$. Each coin is produced by a separate mint and coin $i$ is subject to a seigniorage charge of $\sigma_{i}$. Any revenue obtained from seigniorage is "thrown in the ocean," i.e., disposed of by the government collecting the revenue. ${ }^{16}$

To model a 17th-century monetary environment, it is also necessary to acknowledge the "commodity" nature of contemporary coinage. Following Sargent and Smith (1997) and Sargent and Velde (2002), this is accomplished via a "world market," that is willing to substitute arbitrarily large amounts of silver for goods at constant "world prices" of $\phi$ ounces of silver per debtor good and $\omega$ ounces of silver per creditor good. ${ }^{17}$ Buying or selling a good on the world market incurs a proportional transaction cost equal to the fraction $\tau$. For example, an agent purchasing a debtor good on the world market

\footnotetext{
${ }^{14}$ Both silver and gold coins were used in the Low Countries during the period considered in this paper, but silver became the de facto standard by the mid-17th century. An extension of the model to two precious metals is possible but beyond the scope of the present study.

${ }^{15}$ That is, a creditor owed a debt of $D$ florins may not compel a debtor to pay more than $D / \underline{e}_{i}$ coins of type $i$ in order to settle the debt. However a creditor may be willing to settle for fewer coins if a particular coin is "overvalued" relative to its legal value. As noted above such "overvaluation" or was quite common at the time of the founding of the Wisselbank.

${ }^{16}$ In other words, in order to focus on purely monetary aspects of the 17th century Low Countries economy, we are ignoring the budget constraints of the governments operating the mints. In practice, the stabilization of fiscal policy (by the Dutch Republic) was a precondition for the monetary stabilization achieved by the Wisselbank; see for example, de Vries and van der Woude (1997).

${ }^{17}$ I.e., the Low Countries comprise a "small open economy" with respect to the world silver market.
} 
must pay $\phi /(1-\tau)$ ounces of silver, while an agent selling a debtor good receives only $\phi(1-\tau)$ ounces of silver.

At certain stages during a period, debtors and creditors have access to world markets for their own type of good. That is, debtors may always freely exchange silver for their own type of debtor good, and creditors may exchange silver for their respective creditor goods. There is also an opportunity in each period for agents to use silver (coined or uncoined) to purchase their desired consumption goods on the world market.

The cashiers on the central islands offer their settlement services to arriving old debtors. That is, their banking technology allows cashiers to take in, transfer, and pay out deposits. All coins are valued at market values, subject to the restrictions in the minting ordinance. Any profits realized by the cashiers takes the form of deposited coins that the cashiers need not pay out, and the cashiers can use such coins to obtain consumption goods on the world market. However, the cashiers are sufficiently numerous so as to be perfectly competitive and earn zero profits in equilibrium. ${ }^{18}$

The timing of agents' actions within a period is given in Table 5 below. In the table, the abbreviations YD, YC, OD, and OC are used for young/old debtor/creditors. Goods are abbrieviated as debtor goods (DG), creditor goods (CG), and silver $(\mathrm{S})$. Locations are given by the debtor islands (DI), creditor islands (CI), the world market (WM), and the central island (A). An asterisk indicates that an action is not feasible for a particular group of agents at that particular stage.

\footnotetext{
${ }^{18}$ For notational convenience we set the number of cashiers to exactly equal the number of debtors (or creditors).
} 


\begin{tabular}{|c|c|c|c|c|c|}
\hline & \multicolumn{5}{|c|}{ Table 6: Timing of actions within a period } \\
\hline Stage & YD's & YC's & OD's & OC's & Cashiers \\
\hline 1. & $\begin{array}{l}\text { Can trade } \\
\text { DG for S or } \\
\text { CG }(W M)\end{array}$ & $\begin{array}{l}\text { Can trade } \\
\text { CG for S } \\
\text { (on WM) }\end{array}$ & * & $\begin{array}{c}\text { Can trade S } \\
\text { for DG } \\
\text { (on WM) }\end{array}$ & * \\
\hline 2. & * & $\begin{array}{c}\text { Can mint } \\
\mathrm{S} \text { into } \\
\text { coin }\end{array}$ & * & * & * \\
\hline 3. & * & * & $\begin{array}{c}\text { Deposit } \\
\text { coin with } \\
\text { cashier }(\mathrm{A})\end{array}$ & * & $\begin{array}{l}\text { Credit OD's } \\
\text { for coin } \\
\text { deposited }\end{array}$ \\
\hline 4. & * & * & * & $\begin{array}{c}\text { Present } \\
\text { bills, paid } \\
\text { in coin }(\mathrm{A})\end{array}$ & $\begin{array}{c}\text { Pay bills } \\
\text { presented } \\
\text { by OC's }\end{array}$ \\
\hline 5. & * & * & * & $\begin{array}{l}\text { Can melt } \\
\text { coin, buy } \\
\text { CG (WM) }\end{array}$ & * \\
\hline 6. & $\begin{array}{l}\text { Buy CG's } \\
\text { with bills } \\
\text { (on CI's) }\end{array}$ & $\begin{array}{l}\text { Sell CG } \\
\text { to YDs } \\
\text { for bills } \\
\text { (on CI's) }\end{array}$ & * & $\begin{array}{c}\text { If has CG } \\
\text { can sell } \\
\text { to YD's } \\
\text { (on CI's) }\end{array}$ & * \\
\hline 7. & $\begin{array}{l}\text { Sell DG's } \\
\text { to OC's } \\
\text { for coin } \\
\text { (on DI's) }\end{array}$ & * & * & $\begin{array}{l}\text { Buy DG } \\
\text { from YD's } \\
\text { (on DI's) }\end{array}$ & $\begin{array}{l}\text { If holds } \\
\text { coin, can } \\
\text { buy goods } \\
\text { (on WM) }\end{array}$ \\
\hline 8. & $\begin{array}{c}\text { Can mint, } \\
\text { melt coin } \\
\& \text { buy CG } \\
\text { (on WM) }\end{array}$ & * & * & * & * \\
\hline 9. & & & sumption & urs & \\
\hline
\end{tabular}

Note that for old creditors to benefit from the purchase of creditor goods abroad and subsequent domestic resale of these goods, we must allow for old creditors to negotiate the bills they receive in payment from young creditors. Likewise, a young debtor receiving a bill of another young debtor as payment (from an old creditor who has imported creditor goods), must be allowed to negotiate or "deposit" the bill with a cashier in the following period. This is a reasonable requirement given that, as discussed above, such negotiability was a commonplace feature of 17th century financial obligations. 
The existence of the world markets imposes certain restrictions on prices. In particular, let $p_{x t}^{j}$ be the florin price of debtor goods on debtor island $j$. Then absence of arbitrage implies that for all $i \in I$

$$
\frac{e_{i t} \phi\left(1-\sigma_{i}\right)(1-\tau)}{b_{i}} \leq p_{x t}^{j}
$$

(cf. Sargent and Velde 2002, 27). If condition (4) were violated, then agents could make riskless profits by minting coin $i$, buying up debtor goods on island $j$ and selling the goods on the world market; prices would therefore rise until the inequality was no longer violated. For all $i \in C_{t}$, we must also have

$$
p_{x t}^{j} \leq \frac{e_{i t} \phi}{b_{i}(1-\tau)}
$$

If condition (5) were violated, then agents could earn arbitrage profits by selling goods locally for coin $i$, then melting the coins to buy more goods on the world market. Following Sargent and Velde (2002), we will refer to the bounds in (4) and (5) as "minting" and "melting" points for coin $i$.

If more than one type of coin is in circulation, agents have the option of melting one type of coin and having it minted into another type. The process of melting and reminting is subject to the same transactions costs as other "external" transactions. ${ }^{19}$ This possibility gives rise to the following constraints which must hold for all pairs of coins where $\{i, c\}$ where $i \in I$ and $c \in C_{t}$

$$
\frac{b_{c}\left(1-\sigma_{i}\right)(1-\tau)^{2}}{b_{i}} \leq \frac{e_{c t}}{e_{i t}}
$$

which in fact are implied by the constraints (4) and (5). If condition (6) were violated, then coin $c$ would be undervalued relative to coin $i$, causing agents to melt coin $c$ and mint coin $i$. The bounds defined by (6) correspond to the "gold points" of the classical gold standard.

Similar constraints will apply to the price of creditor goods. Let $P_{y t}^{k}$ be the time- $t$ creditor-island price of creditor goods on island $k$, payable in florins at the central island at time $t+1$. Then the following must hold for all coins $i \in I$

$$
\frac{e_{i, t+1} \omega\left(1-\sigma_{i}\right)(1-\tau)}{b_{i}} \leq P_{y t}^{k}
$$

\footnotetext{
${ }^{19}$ In practice, different magnitudes of transactions costs applied to different types of transactions. In this stylized account we assume these are the same in order to keep the notational burden of the model at a manageable level.
} 
and for all $i \in C_{t}$, we must have

$$
P_{y t}^{k} \leq \frac{e_{i, t+1 \omega}}{b_{i}(1-\tau)}
$$

Conditions (7) and (8) define additional minting and melting points for each coin.

Conditions (4)-(8) together imply bounds on the relative price of debtor versus creditor goods, i.e.,

$$
\frac{\phi(1-\tau)^{2}\left(1-\sigma_{i}\right)}{\omega} \leq \frac{p_{x t}^{j}}{P_{y t}^{k}} \frac{e_{i, t+1}}{e_{i t}} \leq \frac{\phi}{\omega(1-\tau)^{2}\left(1-\sigma_{i}\right)}
$$

for all circulating coins $i$. The fact that agents can both buy and sell goods on the world market implies a more stringent set of bounds on this relative price, i.e.,

$$
\frac{\phi(1-\tau)^{2}}{\omega} \leq \frac{p_{x t}^{j}}{P_{y t}^{k}} \frac{e_{i, t+1}}{e_{i t}} \leq \frac{\phi}{\omega(1-\tau)^{2}}
$$

The money supply in the Low Countries will depend on the florin values of the various coins, their initial stocks, and the amount of minting and melting of the various coins that occurs within a period. The Low Countries' beginning-of-period nominal money stock $M_{t}$, denominated in florins, is given by

$$
M_{t}=\sum_{i \in C_{t}} e_{i t} m_{i t}
$$

where $m_{i t}$ is the stock of coin $i$ at the beginning of $t$. Money evolves according to

$$
M_{t+1}=M_{t}+\sum_{i \in I} e_{i t}\left(\xi_{i t}+n_{i t}\right)-\sum_{i \in C_{t}} e_{i t}\left(\mu_{i t}+\nu_{i t}\right)
$$

where $n_{i t}, \xi_{i t} \geq 0$ represents the number of coins of type $i$ minted by debtors and creditors, respectively, during period $t$, and $\mu_{i t}, \nu_{i t} \in\left[0, m_{i t}\right]$ represents the number of coins of type $i$ melted by debtors and creditors respectively, in period $t$.

\subsection{Golden-rule allocation}

It will be useful to consider a benchmark steady-state allocation in our analysis of this model. Ordinarily one considers Pareto optimal allocations, and equilibria that support such allocations. In the case of commodity money, however, monetary equilibria are known to be inefficient (see e.g., 
Sargent and Wallace 1983), meaning that we must restrict our attention to second-best allocations.

Following Freeman (1996), we focus solely on the golden-rule steadystate allocation that solves the Pareto problem, assigning equal weights to the welfare of all generations apart from the initial old. ${ }^{20}$ This is the steadystate allocation $\left(c_{x}^{*}, c_{y}^{*}, d_{x}^{*}, d_{x}^{* \prime}, d_{y}^{*}, x^{e *}, y^{e *}\right)$ that maximizes

$$
U\left(c_{x}, c_{y}\right)+V\left(d_{x}+\alpha d_{x}^{\prime}, d_{y}\right)
$$

subject to non-negativity constraints on consumptions $c_{x}, c_{y}, d_{x}, d_{x}^{\prime}, d_{y}$, nonnegativity constraints on exports $x^{e}\left(y^{e}\right)$ of debtor (creditor) goods to the world market, and the resource constraints

$$
\begin{gathered}
c_{x}+d_{x}+d_{x}^{\prime} \leq x-x^{e}+\frac{\omega}{\phi}(1-\tau)^{2} y^{e} \\
c_{y}+d_{y} \leq y-y^{e}+\frac{\phi}{\omega}(1-\tau)^{2} x^{e}
\end{gathered}
$$

Given our assumptions about $U$ and $V$, it is straightforward to show that there is a unique solution to this problem, characterized by conditions (14) and (15) at equality, $d_{x}^{\prime}=0$, and the conditions

$$
\frac{\phi(1-\tau)^{2}}{\omega} \leq \frac{U_{x}}{U_{y}}=\frac{V_{x}}{V_{y}} \leq \frac{\phi}{\omega(1-\tau)^{2}}
$$

where the first inequality binds if $x^{e}>0$ and the second inequality binds if $y^{e}>0$. Condition (16) equates marginal rates of substitution across debtors and creditors, and requires both of these be not too far from the "world" marginal rate of transformation $\phi / \omega$, net of transactions costs.

Below we will consider implementation of this allocation under various monetary arrangements.

\subsection{Steady-state monetary equilibria}

We now analyze monetary equilibria in the model, where creditor goods are purchased with bills, bills are discharged by transfer of deposits with cashiers, and debtor goods are purchased with coin. We restrict our attention to steady-state equilibria (and temporary deviations therefrom) that are symmetric across islands.

\footnotetext{
${ }^{20}$ We also keep the utility of the cashiers at their reservation level, i.e., zero. At the cost of more notational complexity, we could apply the same approach to more general classes of second-best allocations.
} 
The typical debtor's problem is to choose $d_{x t}, d_{x, t+1}^{\prime}, d_{y t}, n_{i t}, \mu_{i t}, z_{t}^{d}, h_{t}$ so as to maximize

$$
V\left(d_{x t}+\alpha d_{x, t+1}^{\prime}, d_{y t}\right)
$$

where $z_{t}^{d}$ denotes the export of the debtor's endowment good for purpose of obtaining silver to buy creditor goods on the world market, and $h_{t}$ is the nominal quantity of bills issued by the debtor in Stage 6 of period $t$. The debtor is subject to nonnegativity constraints on exports, consumption, melting, and minting, a cap on melting given by the stock of each circulating coin, and the following constraints (where by symmetry we have dropped locational superscripts on all prices)

$$
\begin{gathered}
\underline{M}_{t} \leq \\
p_{x t}\left(x-d_{x t}-\sum_{i \in I} \frac{b_{i}}{\phi\left(1-\sigma_{i}\right)(1-\tau)} n_{i t}-z_{t}^{d}+\sum_{i \in C_{t}} \frac{b_{i}(1-\tau)}{\phi} \mu_{i t}\right) \\
h_{t}+p_{x, t+1} d_{x, t+1}^{\prime} \leq \underline{M}_{t}+\sum_{i \in I} e_{i t} n_{i t}-\sum_{i \in C_{t}} e_{i t} \mu_{i t} \\
P_{y t}\left(d_{y t}-\frac{\phi(1-\tau)^{2}}{\omega} z_{t}^{d}\right) \leq h_{t}
\end{gathered}
$$

where $\underline{M}_{t}$ denotes money brought by creditors to debtor islands in Stage 7 of period $t$. Constraint (18) is a budget constraint and states that the amount of money that a young debtor receives in the first period of life cannot exceed the value of his net supply of debtor goods to Low Countries markets (as opposed to the world market). The latter is given by the value of his endowment, minus his consumption, minus the quantity of the good exchanged to obtain silver for coinage, minus the amount of the good exported to obtain his desired creditor good on the world market, plus any quantity of the good obtained by melting coin and purchasing the good on the world market. Constraint (19) is a "settlement constraint" and states that coin is necessary to redeem debt issued to purchase creditor goods, or to purchase debtor goods in the second period of life. Finally, constraint (20) requires that the debtor issue bills to cover any period- $t$ purchases of creditor goods made in Low Countries.

First-order conditions for this problem reduce to the following set of conditions. First,

$$
\frac{e_{i, t+1} \phi\left(1-\sigma_{i}\right)(1-\tau)}{b_{i} P_{y t}} \leq \frac{V_{x t}}{V_{y t}}
$$


for $i \in I$, where (21) holds with equality for $i$ such that $n_{i t}>0$. Second,

$$
\frac{V_{x t}}{V_{y t}} \leq \frac{e_{i, t+1} \phi}{P_{y t} b_{i}(1-\tau)}
$$

for $i \in C_{t}$ where (22) holds with equality for $i$ such that $\mu_{i t}>0$. Since debtors always have the option of purchasing some of their desired creditor good on the world market, we must also have

$$
\frac{\phi(1-\tau)^{2}}{\omega} \leq \frac{V_{x t}}{V_{y t}}
$$

with equality if $z_{t}^{d}>0$. Finally,

$$
\frac{\alpha V_{x t}}{V_{y t}} \leq \frac{p_{x, t+1}}{P_{y t}}
$$

with equality for $d_{x, t+1}^{\prime}>0$.

The typical creditor's problem is to maximize

$$
U\left(c_{x, t+1}, c_{y t}\right)
$$

over $c_{x, t+1}, c_{y t}, \xi_{i t}, \nu_{i, t+1}, z_{t}^{c}, \ell_{t+1}$, where $z_{t}^{c}$ denotes exports for purchasing debtor goods on the world markets, and $\ell_{t+1}$ denotes the florin value of bills held by the creditor at time- $t+1$. The creditor is subject to nonnegativity constraints as well as the following constraints

$$
\begin{aligned}
\ell_{t+1} \leq \frac{e_{j, t+1} P_{y, t+1}}{e_{j, t+2}}( & \left.\sum_{i \in C_{t}} \frac{b_{i}(1-\tau)}{\omega} \nu_{i, t+1}\right)+ \\
& P_{y t}\left(y-c_{y t}-\sum_{i \in I} \frac{b_{i}}{\omega\left(1-\sigma_{i}\right)(1-\tau)} \xi_{i t}-z_{t}^{c}\right),
\end{aligned}
$$

for all circulating coins $j$, and

$$
\begin{aligned}
p_{x, t+1}\left(c_{x, t+1}-\frac{\omega(1-\tau)^{2}}{\phi} z_{t}^{c}\right) & \leq \\
& \ell_{t+1}+\sum_{i \in I} e_{i, t+1} \xi_{i t}-\sum_{i \in C_{t}} e_{i, t+1} \nu_{i, t+1}
\end{aligned}
$$

Constraint (26) says that $\ell_{t+1}$ cannot exceed the $t+1$ value of goods sold by the creditor (either in period $t$ or in period $t+1$ through importation). 
Constraint (27) says that the value of the debtor goods purchased by the debtor in the Low Countries cannot exceed the value of bills due the creditor, plus net coinage on the part of the creditor. For constant florin values $e$, first-order conditions reduce to

$$
\left(\frac{p_{x, t+1} b_{i}(1-\tau)}{e_{i, t+1} \omega}\right)\left(\frac{P_{y, t+1}}{P_{y, t}}\right) \leq \frac{U_{x, t+1}}{U_{y t}} \leq \frac{p_{x, t+1}, b_{i}}{e_{i, t+1} \omega\left(1-\sigma_{i}\right)(1-\tau)}
$$

where the first inequality binds if (circulating) coin $i$ is melted, and the second inequality binds if coin $i$ is minted, and

$$
\frac{U_{x, t+1}}{U_{y t}} \leq \frac{\phi}{\omega(1-\tau)^{2}}
$$

with equality if $z_{t}^{c}>0$.

Operating under a zero-profit constraint, cashiers face a trivial optimization problem, i.e. there is only one course of action open to them. This consists of accepting deposits from creditors in Stage 3 of each period, transferring balances and paying them out to depositors in Stage 4. Note that at the end of Stage 3 of period $t$, the typical banker has liabilities of $\ell_{t}$ florins in the form of deposits that must cover bills to be presented in Stage 4 by generation $t-1$ creditors, and assets of

$$
\underline{M}_{t-1}+\sum_{i \in I} e_{i t} n_{i, t-1}-\sum_{i \in C_{t}} e_{i t} \mu_{i, t-1}-p_{x, t} d_{x, t}^{\prime}
$$

in the form of deposits of generation $t-1$ debtors. In equilibrium, these amounts must clearly be the same, and the coins deposited by the debtors will be the coins received by the creditors.

A steady-state monetary equilibrium can now be defined as a time invariant collection of the following: a vector of consumptions $\left(c_{x}, c_{y}, d_{x}, d_{x}^{\prime}, d_{y}\right)$, a vector of exports $\left(z^{c}, z^{d}\right)$, a set of prices $\left(p_{x}, P_{y}\right)$, a set of florin values $e \geq \underline{e}$ for all coins in $I$, a set of circulating coins $C \subseteq I$, a vector of stocks of circulating coins $m_{c}$, and a set of minting-and melting vectors $\{n, \mu, \xi, \nu\}$ such that creditors' and debtors' first-order conditions as well as budget and settlement constraints are satisfied, markets clear, conditions (5) and (8) hold for all $i \in C$, conditions (4) and (7) hold for $i \in I$, cashiers' balance sheets balance, and condition (10) holds. In such an equilibrium the total stock of money $M$ is constant.

So defined, the set of steady-state monetary equilibria is potentially quite large. The principal difficulty is that there is no way to uniquely determine the value of a "florin." Again we appeal to historical experience and consider a subset of equilibria that satisfy the following restriction: 
Condition 1 Let $g \in I$ be a coin with the greatest minting point according to the values assigned in the minting ordinance, i.e., a coin for which

$$
\frac{\underline{e}_{g}\left(1-\sigma_{g}\right)(1-\tau)}{b_{g}} \geq \frac{\underline{e}_{i}\left(1-\sigma_{i}\right)(1-\tau)}{b_{i}}
$$

for all $i \in I$. Then the market value of coin $g$ equals its legal value, i.e., $e_{g}=\underline{e}_{g}$.

This restriction is motivated by the following considerations. We interpret the minting ordinances as giving a creditor the option of demanding payment in some lawful coin at its lawfully specified value. In other words, not all coins may be simultaneously overvalued, so that the market value of at least one coin must equal its legal value. Condition 1 specifies that this is the coin that provides a debtor with the greatest number of florins per ounce of precious metal minted. This would be the least costly means by which a debtor (or cashier) could hold to the letter of the minting ordinance, should a creditor make this demand.

The following result establishes that under mild conditions, the goldenrule allocation can be implemented as a steady-state monetary equilibrium.

Proposition 2 Let $g \in I$ be a coin with the greatest minting point according to the values assigned in the minting ordinance. If $\left(1-\sigma_{g}\right)<(1-\tau)^{2}$ and $\alpha>0$ is sufficiently small, then the golden-rule allocation can be supported as a steady-state monetary equilibrium satisfying condition 1, in which only coin $g$ circulates.

Proof. See Appendix A.

Corollary 3 If in addition, there are other coins $i \in I$ for which (1$\left.\sigma_{i}\right)<(1-\tau)^{2}$, then the golden-rule allocation can be supported as a steadystate monetary equilibrium satisfying condition 1, in which all such coins circulate.

Proof. See Appendix A.

$<$ Figure to be added. $>$

It should be emphasized that in the economies described above, prices are all defined in terms of the unit of account, and not in terms of any particular coin. Steady-state monetary equilibria may involve the circulation of only a single coin, or multiple coins. If there is more than one circulating 
coin, the equilibrium displays Sargent and Smith's (1997) "anti-Gresham's law" property, i.e., that the relative values of the circulating coins are not uniquely determined by their precious metal content. This feature of the model is consistent with the monetary situation prevalent at the time of the founding of the Wisselbank.

\section{M odeling a debasement}

Corollary 3 illustrates how a stable-price equilibrium is a feasible outcome under a commodity money regime with multiple mints. Prior to the founding of the Wisselbank, however, the Dutch economy suffered from inflation, due to a succession of debasements in its stocks of coin. We now provide some examples of how a debasement might work in the context of the model. For simplicity we consider the effects of a one-time unanticipated debasement, followed by a return to steady state after a single period of adjustment. ${ }^{21}$

We begin by considering the special case where there is only one mint and there is only one Low Countries coin in circulation (call this the rixdollar). Without loss of generality this coin is assigned a florin value of $e=1$. Up until time $t$, the economy is in a steady-state equilibrium that supports a golden-rule allocation which does not require the export of either debtor or creditor goods. The steady-state money stock (=stock of rixdollars) is given by $M=m$, the steady-state florin price of debtor goods is $p_{x}^{*}$ and bills of exchange drawn by young debtors to purchase creditor goods are worth $P_{y}^{*}$ florins the following period. Rixdollars contain $b$ ounces of silver and are freely minted at a seigniorage charge of $\sigma$.

At the beginning of period $t$, the mint announces a debasement of the rixdollar. A debasement is defined as a choice of new silver content $b^{\prime}<b$ and a new seigniorage charge $\sigma^{\prime}$, where the mint is willing to freely mint silver, including old "heavy" rixdollars, into new "light" rixdollars at a seigniorage charge of $\sigma^{\prime}$. To be successful, a debasement must induce old debtors to turn in their old rixdollars for reminting. ${ }^{22}$ Debtors will do this if they are

\footnotetext{
${ }^{21}$ We study these "adjustment periods" as convenient proxies for the intervals of transition following a debasement.

${ }^{22}$ We will assume that old debtors always have access to mints immediately following such announcements.
} 
left with more rixdollars after reminting than before, i.e., if ${ }^{23}$

$$
\hat{m} \equiv \frac{m b\left(1-\sigma^{\prime}\right)}{b^{\prime}} \geq m
$$

(cf. Sussman and Zeira 2003, 1779) where $\hat{m}$ is the number of coins after reminting, which is equivalent to requiring that the minting point of the new rixdollar exceed the melting point of the old,

$$
\frac{1}{b} \leq \frac{1-\sigma^{\prime}}{b^{\prime}}
$$

It is immediately apparent from (32) and (33) that an unanticipated debasement can increase the money stock and shift no-arbitrage conditions (4), (5), (7), and (8). What is perhaps less apparent that an unanticipated debasement can lead to an increase in demand for the debased coin. To see this, consider the no-arbitrage conditions following a debasement

$$
\begin{aligned}
& \frac{\phi\left(1-\sigma^{\prime}\right)(1-\tau)}{b^{\prime}} \leq p_{x} \leq \frac{\phi}{b^{\prime}(1-\tau)} \\
& \frac{\omega\left(1-\sigma^{\prime}\right)(1-\tau)}{b^{\prime}} \leq P_{y} \leq \frac{\omega}{b^{\prime}(1-\tau)}
\end{aligned}
$$

Clearly the first inequalities in conditions (34) and (35) will be violated for pre-debasement prices $\left(p_{x}, P_{y}\right)=\left(p_{x}^{*}, P_{y}^{*}\right)$, for a sufficiently large debasement (sufficiently small but positive $b^{\prime}$ ). In other words, if the domestic "silver equivalent" price of either debtor (or creditor) goods becomes cheap enough, debtors (or creditors) will be tempted to export their endowment goods and buy their desired consumption good domestically. To make these purchases, they need to convert the silver they earn by exporting their endowment to domestic coinage, resulting in an increased demand for the debased coin and ultimately, an increase in prices of both types of good.

More formally, we have the following results.

Lemma 4 Suppose that the one-coin economy is in a steady-state monetary equilibrium that supports the golden-rule allocation, which does not require

\footnotetext{
${ }^{23}$ Note that the transaction cost $\tau$ does not arise when a coin is reminted into a coin of the same type. Also note under the overlapping generations structure, old debtors always prefer to remint under condition (32), since they cannot consume after their second period of life. In practice, debasements sometimes led to the differentiation of a single coin into two distinct coins, i.e., the "new" (debased) and "old" (nondebased) coin. See Rolnick, Velde, and Weber (1996) for some medieval examples.
} 
the export of debtor or creditor goods. Then for a sufficiently large unanticipated debasement (sufficiently small $b^{\prime}>0$ ), the original equilibrium cannot hold.

P roof. As noted above, a sufficiently small $b^{\prime}$ causes the first inequalities in (34) and (35) to be violated.

P roposition 5 In the one-coin economy, if such a debasement occurs where $\sigma^{\prime}=\sigma$ and endowments are sufficiently large, then: (i) The economy can return to a new steady-state monetary equilibrium after a one-period transition, where the equilibrium allocation again corresponds to the golden-rule allocation. (ii) In the new equilibrium, both prices and the nominal money stock are (weakly) higher than in the original equilibrium. (iii) The transition to the new equilibrium will sometimes require the export of goods and additional minting of the debased coin.

\section{Proof. See Appendix A.}

$<$ Figure to be added. $>$

Proposition 5 illustrates a paradoxical feature of commodity-money systems, that a debasement can actually lead to a surge in minting of the debased coin. ${ }^{24}$ This can occur because a debasement not only increases the nominal money stock but also exerts upward pressure on prices through no-arbitrage conditions (34) and (35). To maintain a constant real money stock, additional coinage is sometimes required.

Proposition 5 also allows us to characterize the deleterious effects of an unanticipated debasement. Such a debasement imposes two types of costs on an economy. The first type of cost is comparable to the cost associated with unanticipated fiat money inflation, i.e., a transfer of wealth from creditors holding nominal obligations to the debtors whose obligations they hold, which leads to inefficient allocations of goods in the period where the inflationary shock occurs. A sufficiently large debasement will also give rise to a second type of cost, which is the value of consumption foregone as goods are

\footnotetext{
${ }^{24}$ Rolnick, Velde, and Weber (1996) extensively document this phenomenon in the case of medieval England and France. They refer to such surges as a "puzzle," but the proof of Proposition 5 shows that this puzzle is at least partly explained by the arithmetic of debasements. They also argue that gains to debtors resulting from debasements should not have been "renegotiation-proof," in the sense that creditors and debtors should have been able to strike contracts that allowed for side payments in the event of a debasement. We note that in practice such contracts would have involved at least one third party, a cashier, making the negotiation and enforcement of such contracts potentially quite costly.
} 
exported in order to expand the real stock of money to its pre-debasement level.

This second type of cost is of course nothing more an illustration of the well-known inefficiency of commodity money: maintaining a commodity standard imposes an opportunity cost on money holders. The point of the foregoing analysis is demonstrate the manner in which this inefficiency was prone to manifest itself, given the institutions of Early Modern Europe.

\subsection{Debasement with multiple mints}

We now consider the effects of a debasement in an economy where coins from competing mints circulate. For simplicity we focus on an economy with only two mints, each of which produces a single coin. Call these coins the "rixdollar" (coin $\rho$ ) and "cross rixdollar" ( coin $\gamma$ ), and denote their initial silver contents, seigniorage rates, and minting-ordinance values as $b_{r}\left(b_{c}\right)$, $\sigma_{r}\left(\sigma_{c}\right)$, and $\underline{e}_{r}\left(\underline{e}_{c}\right)$ respectively.

Up until time $t$, the economy is in a steady-state monetary equilibrium satisfying Condition 1, that supports a golden-rule allocation that requires no exports (by Corollary 3 this is possible if $\alpha, 1-\sigma_{r}$, and $1-\sigma_{c}$ are small enough). The steady-state coin stocks are given by $m_{r}>0$ and $m_{c}>0$. Let us suppose that coin $\gamma$ that circulates at its minting-ordinance value, i.e., we have $e_{c}=\underline{e}_{c}$ and $e_{r} \geq \underline{e}_{r}$. Under Condition 1, the legal minting point of coin $\gamma$ exceeds that of coin $\rho$. The steady-state money stock is given by

$$
M=e_{r} m_{r}+e_{c} m_{c}
$$

At the beginning of period $t$, the mint producing cross rixdollars announces a debasement of the cross rixdollar from $b_{c}$ to $b_{c}^{\prime}<b_{c}$; the metal content of the rixdollar does not change. ${ }^{25}$ As in the single-coin case, a sufficiently severe debasement may lead to melting of the old coinage and minting of the new. Either one coin or both may be melted, according to interactions between the drop in the silver content of the cross rixdollar, and the florin value that agents place on the rixdollar. Let $e_{r}^{\prime}$ and $e_{c}^{\prime}$ be the florin values assigned to the two coins following the debasement. Supposing

\footnotetext{
${ }^{25}$ Another form of debasement was commonly practiced in the early years of the Republic (Korthals Altes, chapter 3). This was to "lighten" domestic coinage by passing a minting ordinance that assigned a higher florin value to domestic coins, while keeping the florin value of foreign coins at existing values. An analysis very similar to that presented below could also be applied to this second sort of debasement.
} 
that $e_{c}^{\prime}=e_{c}$, cross rixdollars will be reminted as long as

$$
\frac{1}{b_{c}} \leq \frac{1-\sigma_{c}^{\prime}}{b_{c}^{\prime}}
$$

(cf. condition (33)), and rixdollars will be melted down and minted into cross rixdollars as long as

$$
\frac{e_{r}^{\prime}}{b_{r}(1-\tau)}<\frac{e_{c}\left(1-\sigma_{c}^{\prime}\right)(1-\tau)}{b_{c}^{\prime}}
$$

(cf. condition (6)). The following result more precisely characterizes the effects of an unanticipated debasement of the cross rixdollar.

Proposition 6 In the two-coin economy, suppose that coin $\gamma$ is subject to an unanticipated debasement in which the seignorage rate $\sigma_{c}$ does not change, i.e., $\sigma_{c}^{\prime}=\sigma_{c}$. Then if condition (37) holds, condition (38) holds for $e_{r}^{\prime}=e_{r}$, and endowments are sufficiently large: (i) The economy can return to a new steady-state monetary equilibrium after a one-period transition, where the equilibrium allocation again corresponds to the golden-rule allocation. (ii) In the new equilibrium, only the debased coin circulates, and both prices and the nominal money stock are (weakly) higher than in the original equilibrium. (iii) The transition to the new equilibrium will sometimes require the export of goods and additional minting of the debased coin.

Proof. See Appendix A.

Proposition 6 provides an example of "Gresham's law," in which "bad" money (debased coin) drives out "good" (the non-debased or "full-weight" coin), in the sense that the full weight coin is completely eliminated from circulation. As discussed above, the historical record suggests that debasements often did not always drive out full-weight coin, but instead resulted in its continued circulation at a value exceeding its legal value. This phenomenon can be captured in the model if we allow the florin value of the full-weight coin to appreciate following a debasement of the competing coin.

Corollary 7 If $e_{r}^{\prime}$ can appreciate in response to the debasement of coin $\gamma$, then both coins can circulate in the new equilibrium.

P roof. See Appendix A.

The debasement in Proposition 6 corresponds to the sort of "predatory" debasement that was common during the early years of the Dutch Republic. 
A well-designed debasement (or for that matter, a convincing counterfeit by an illicit mint) could be used to extract silver from the Dutch economy. In the model, the cost of such extractions is borne not only by the creditors unfortunate enough to be repaid in debased coin, but also by agents who must export goods in order to obtain sufficient coinage for future transactions.

The much despised practices of bicquetteeren and steygeringhe can be seen as market responses to such predatory debasements. Following a debasement, people often chose to hold back full-weight coins and export them (possibly for reminting into debased coin). In the model, this response is optimal if condition (38) holds. On the other hand, for a sufficient increase in the florin value of the full-weight coin, it becomes optimal for debtors

to retain these coins. Such "overvaluation," in effect, transfers a portion of the seigniorage revenue from a surprise debasement away from the debasing mint and to the holders of the full-weight coin. In the model, Corollary 7 shows that such "overvaluation" of the heavy coin can be consistent with a new equilibrium, as long as agents share a common belief in its occurrence.

The ability of competing mints to engage in such predatory debasements thus amounted to a power to place a destructive tax on the economic activities of the Dutch Republic and its surrounding economies. One solution to this problem would have been a prohibition on the use of foreign coins. Lacking the power to enforce such a prohibition, the Republic was reduced to reforming its minting ordinances, so as to bring them closer in line with market valuations. Such efforts were bound to fail, however, since successive minting ordinances did nothing to change the mints' incentives to debase.

\section{The model with an exchange bank}

The model is now modified to include an exchange bank that resembles the Wisselbank in a number of key respects. In order to keep the notation manageable, the set of coins is restricted to the two coins $\gamma$ and $\rho$ considered above. We focus on the operations of the Wisselbank in its mature form, i.e., the period from 1683 onwards, after the official recognition of the distinction between bank money and current money, and after the introduction of receipts.

In this modified version of the model, the settlement function of the cashiers is taken over by the exchange bank. The exchange bank issues two forms of liabilities, bank balances which are not redeemable in coin, and receipts which are. Like the Wisselbank, the exchange bank is willing to trade bank funds for receipts. We abstract from the miniscule redemption 
fee actually charged by Wisselbank, and suppose that the exchange bank is willing to exchange receipts for bank funds one-for-one.

In Stage 3 of each period, old debtors bring receipts they have received from sales of their endowment goods in each period. Since they need bank balances to settle the bills they drew last period, they exchange these receipts at the Wisselbank for bank balances. In Stage 4 the old debtors transfer these balances to old creditors, who then exchange them for receipts. The receipts can be taken to the debtor islands and traded for the endowment goods of young debtors.

A key distinction between the exchange bank and the cashiers in the previous section is that balances on accounts at the exchange bank become the effective numeraire for all transactions. More specifically, exchange bank balances are denominated in banco florins. An agent may obtain an advance of bank funds by posting either heavy money or current money as collateral with the bank. The agent also obtains a transferable receipt entitling him to return of the coins posted. If a posted coin $i$ is deemed to be heavy money, then the bank credits the agent $\underline{e}_{i}$ banco florins per coin, i.e., the agent is credited for the minting-ordinance value of the coin. On the other hand, if a posted coin $i$ is deemed to be current money, then the agent is credited $\delta \underline{e}_{i}$ banco florins per coin, where $\delta=1 /(1+a)$ and $a$ is the agio or premium on banco versus current florins. In terms of current florins, a heavy-money coin $i$ would be worth $(1+a) \underline{e}_{i}$ current florins while a current-money coin would be worth $\underline{e}_{i}$ current florins.

Following late 17th-century practice, prices are now denominated in banco florins. As in the previous section, we assume that the legal minting point of coin $\gamma$ exceeds that of coin $\rho$, so that rixdollars are full-weight and cross rixdollars are current money. The stock of circulating receipts at the beginning of time $t$ is then given by

$$
\mu_{t}=\underline{e}_{r} \bar{m}_{r, t}+\delta \underline{e}_{c} \bar{m}_{c, t}
$$

where $\bar{m}_{i, t}$ denotes the quantity of coins of type $i$ posted at the exchange bank. Barring any redemptions of the receipts, or posting of additional coin at the Wisselbank, the stock of bank balances outstanding at the end of Stage 3 of period $t$ is also given by $\mu_{t}$.

The representative debtor's and creditor's problems remain much the same as above, except that in (18), (19), (26), and (27), $e_{c t}$ and $e_{r t}$ are constrained to equal $\delta \underline{e}_{c}$ and $\underline{e}_{r}$ respectively. The following result is then straightforward. 
Proposition 8 In the two-coin economy with an exchange bank, suppose that $\left(1-\sigma_{i}\right)<(1-\tau)^{2}$ for $i=\gamma, \rho$ and $\alpha>0$ is sufficiently small. Then for some agio on banco florins $a>0$ the golden-rule allocation can be supported as a steady-state monetary equilibrium, in which stocks of both coins remain at the exchange bank, debtor goods are purchased with receipts, and creditor goods are purchased with bills settled in bank funds.

Proof. (Sketch).As in Proposition 2 and Corollary 3, the key is to make sure that agents have no incentive to mint or melt either coin (in this case, after redeeming a receipt). This can be done if the bank chooses the agio $a$ such that the minting points of the two coins are identical, i.e., choose $a$ such that

$$
\left(\frac{1}{1+a}\right)\left(\frac{\underline{e}_{c}\left(1-\sigma_{c}\right)}{b_{c}}\right)=\left(\frac{\underline{e}_{r}\left(1-\sigma_{r}\right)}{b_{r}}\right)
$$

The rest of the proof proceeds as in Proposition 2 and Corollary 3.

In other words, a judicious choice of agio could always allow both "heavy" and "light" coins to be valued in exchange. Note that neither type of coin need actually circulate, only the receipts for these coins.

The true value of the agio lay in its ability to be upwardly adjusted in response to a downward shift in the metallic content of current money. Suppose that the economy is in the steady-state equilibrium described in Proposition 8, and that the metal content of coin $\gamma$ is unexpectedly decreased from $b_{c}$ to $b_{c}^{\prime}$. In response, the exchange bank could announce an increase in the agio from $a$ to $a^{\prime}$. Reminting incentive conditions (37) and (38) become

$$
\frac{1}{(1+a) b_{c}}<\frac{1-\sigma_{c}^{\prime}}{\left(1+a^{\prime}\right) b_{c}^{\prime}}
$$

and

$$
\frac{\underline{e}_{r}}{b_{r}(1-\tau)}<\frac{\underline{e}_{c}\left(1-\sigma_{c}^{\prime}\right)(1-\tau)}{\left(1+a^{\prime}\right) b_{c}^{\prime}},
$$

respectively. Evidently, for a sufficient increase in the agio (sufficiently large $\alpha^{\prime}$ ), neither condition is satisfied and agents have no incentive to redeem receipts, withdraw coins, and have them reminted. Moreover, the agio can always be adjusted so that the minting point for the debased coin $\gamma$ will exactly equal the minting point coin $\gamma$ before the debasement, i.e., so that for example condition (40) will continue to hold after the debasement.

These considerations prove the following: 
Proposition 9 In the two-coin economy with an exchange bank, suppose that the economy is in a steady-state monetary equilibrium described in Proposition 8. If coin $\gamma$ is subject to an unanticipated debasement in which the seignorage rate $\sigma_{c}$ does not change, then so long as the agio on banco money sufficiently increased: (i) the original equilibrium remains an equilibrium, and (ii) neither coin is melted and reminted in response to the debasement.

Mints' incentives to debase can thus be curtailed under a monetary system in which debts are denominated in bank money and settled on the books of an exchange bank. Under this arrangement, exchange bank money becomes the numeraire, and changes in the metal content of "current money" become irrelevant for agents' decisions.

\subsection{Comparison with the "standard formula"}

The role of Wisselbank money as a "virtual currency" bears a certain resemblance to Cipolla's (1956) "standard formula" for the issue of multipledenomination coins under a commodity monetary standard. This formula calls for an explicit commodity standard to be maintained for only a single, large-denomination coin. Additional coins are issued as inherently worthless, difficult-to-counterfeit tokens redeemable at a fixed rate of exchange with the reference coin.

Sargent and Velde (2002) provide numerous historical examples of how failure to adhere to this formula led to debasement and/or disappearance of precious-metal coins. In their account, the driving force behind this monetary instability is the specific role of small-denomination coins in certain transactions, i.e., everyday small-value transactions that can only be settled with small denomination coins. By the early 20th century, these problems were ameliorated after most major economies adopted the standard formula. ${ }^{26}$

Three centuries earlier, the Dutch Republic came quite close to replicating Cipolla's recommendation. By effectively imposing a legal requirement that financial transactions be settled at the Wisselbank, Amsterdam ultimately created a sort of "virtual token coin" in the form of bank money redeemable in heavy coin. Counterfeiting was ruled out since money created by the Wisselbank only existed as bank balances.

\footnotetext{
${ }^{26}$ The first statement of the standard formula is attributed to a proposal by the master of the London Mint, Sir Henry Slingsby, in 1661. Slingsby was no doubt familiar with the the experience of the Bank of Amsterdam, which may have influenced his views on token money.
} 
With the emergence of the banco florin as a separate and dominant unit of account, however, Wisselbank money eventually surpassed its role as a redeemable token currency. As the banco florin became the effective numeraire for financial transactions within the Dutch Republic, the monetary role of coin was deemphasized, while central bank money assumed an unprecedented preeminence.

\section{Conclusion}

Today central banks are commonly thought of as entities that issue notes, operate a discount window, and conduct open market operations in government securities. However, central banks evolved from an earlier type of institution, a trusted cashier or "exchange bank" for the settlement of commercial transactions. The Bank of Amsterdam or Wisselbank formed the crucial link between exchange banks and the central banks that would follow. Like the exchange banks, it served as a trusted cashier, but it also came to provide an "artificial" numeraire good that served as a stable store of value. Critical to the success of the Wisselbank was its creation of a separate unit of account not tied to any particular coin, but instead to the liabilities of a public institution. This success of this idea did not require the issue of notes, a discount window, or purchases of bonds, but instead derived from the Wisselbank's legal monopoly on the operation of a large-value payment system within the city of Amsterdam.

The initial impetus for this innovation was to control the problems associated with the Dutch Republic's lack of a standardized coinage, and the attendant incentives of local governments to engage in destructive debasements. The model presented above illustrates how such incentives could arise, and how the introduction of central bank money served to blunt these incentives.

Our argument is not meant to suggest that the price stability engendered by the Wisselbank was an automatic consequence of the founding of a central bank. Crucial to the success of the Wisselbank was the strong political support it enjoyed. Other institutions conceived along the same lines as the Wisselbank, did not always enjoy the same degree of political support and enjoyed less success in terms of currency stabilization. Moreover, the Wisselbank ultimately became illiquid at the end of 18th century, as the value of its backing assets (which by then included large amounts of the debt of the Dutch East India Company) declined and Amsterdam fell to France in 1798. The Wisselbank's downfall, however, came only after it had 
provided the Dutch Republic with over a century of stable prices: then as now, an enviable accomplishment in the real world of monetary policy. 


\section{A ppendix A: Proofs}

\subsection{Proof of Proposition 2}

Initially suppose there is only one coin so that $I=\{g\}$. Let $M R S^{*}$ be the steady-state marginal rate of substitution implied by the golden-rule allocation, i.e., the marginal rate of substitution given in (16).

Suppose further that the golden-rule allocation does not involve trade

with the world market, i.e., suppose that $M R S^{*} \in\left(\frac{\phi(1-\tau)^{2}}{\omega}, \frac{\phi}{\omega(1-\tau)^{2}}\right)$. Choose a candidate equilibrium $p_{x}$ as

$$
p_{x}^{*}=\frac{e_{g} \phi(1-\tau)}{b_{g}}
$$

and $P_{y}^{*}=p_{x}^{*} / M R S^{*}$. Then as long as $\left(1-\sigma_{g}\right)<(1-\tau)^{2}$, it is straightforward to verify that $p_{x}^{*}$ and $P_{y}^{*}$ satisfy no-arbitrage conditions (4)-(10) with strict inequality in all cases, i.e., no minting, melting, or trade with the world market occurs. Under these prices, first-order conditions for the debtor's and creditor's problem can also be shown to hold for the consumptions in the golden-rule allocation, again with strict inequality for $\alpha$ sufficiently small.

Now suppose that the golden-rule allocation requires exporting debtor goods to the world market in return for creditor goods. This allocation can be implemented by choosing a slightly lower value for $p_{x}$, e.g.,

$$
p_{x}^{* *}=\frac{e_{g} \phi(1-\tau)^{2}}{b_{g}}
$$

and again choosing $P_{y}$ as

$$
P_{y}^{* *}=\frac{p_{x}}{M R S^{*}}=\frac{e_{g} \omega}{b_{g}}
$$

It is again straightforward to show that no-arbitrage and first-order conditions will hold at the golden-rule allocation. However, the first-order condition (23) and the first part of no-arbitrage condition (10) will hold with equality in this case.

If the golden-rule allocation requires exporting creditor goods, the supporting monetary equilibrium can be constructed in a symmetric fashion.

Now consider the more general case where $I \supseteq\{g\}$. Then if we take $e=\underline{e}$, then the monetary equilibrium described above exists, where only coin $g$ circulates. At prices $\left(p_{x}^{*}, P_{y}^{*}\right)$ agents have no incentive to mint any other coin, since the minting point of $g$ is by definition at least as great 
as that of all other coins so long as $e=\underline{e} .\left(p_{x}^{*}, P_{y}^{*}\right)$ (or $\left.\left(p_{x}^{* *}, P_{y}^{* *}\right)\right)$ is also chosen so that there is no incentive for agents to melt coin $g$. Therefore an equilibrium exists where the entire money stock consists of coin $g$.

\subsection{Proof of Corollary 3}

Let $H$ be the set of all coins $i$ for which $\left(1-\sigma_{i}\right)<(1-\tau)^{2}$. and let $F_{i}(e)$ be the set of prices $\left(p_{x}, P_{y}\right)$ for which (4)-(10) are satisfied for coin $i$ in steady state when market valuations of coins are given by $e$. Choose $e$ as $e=e^{*}$, where

$$
e_{i}^{*}=\left\{\begin{array}{cl}
\underline{e}_{i} & \text { if } \quad i=g \text { or } i \in I \backslash H \\
\frac{\underline{e}_{g} b_{i}\left(1-\sigma_{g}\right)}{b_{g}\left(1-\sigma_{i}\right)} \geq \underline{e}_{i} & \text { if } \quad i \in H \backslash\{g\}
\end{array}\right.
$$

which aligns the minting points of coins in $H$ with the minting point of coin $g$, and sets the minting points of all coins in $I \backslash H$ to be below the minting point of $g$. It can then be verified that there exists some coin $h \in H$ s.t. $F_{h}\left(e^{*}\right)=\bigcap_{i \in H} F_{i}\left(e^{*}\right)$. Mimicking the proof of the Proposition and substituting $e_{h}^{*}$ for $e_{g}$, we can now choose $\left(p_{x}^{*}, P_{y}^{*}\right) \in F_{h}\left(e^{*}\right)$ that will support the golden-rule allocation. At these prices there is no incentive to mint any coin, and there is no incentive to melt any coin in $H$; therefore an equilibrium exists in which all coins in $H$ circulate.

\subsection{Proof of Proposition 5}

Let $m$ denote the initial equilibrium stock of coins and $p_{x}^{*}$ and $P_{y}^{*}$ be the initial equilibrium prices of debtor and creditor goods, respectively. Following the debasement, the stock of coins increases (weakly) to $\hat{m}$. We consider three candidate new equilibria.

Candidate equilibrium 1 (No goods are exported). As initial candidates for the new steady-state equilibrium stock of coins and prices $m^{\prime}, p_{x}^{\prime}, P_{y}^{\prime}$, take

$$
\begin{aligned}
m^{\prime} & =\hat{m} \\
p_{x}^{\prime} & =\left(\frac{\hat{m}}{m}\right) p_{x}^{*} \\
P_{y}^{\prime} & =\left(\frac{\hat{m}}{m}\right) p_{y}^{*}
\end{aligned}
$$

Since this involves just a proportional increase in money and prices, there will be a new steady-state monetary equilibrium with the same equilibrium allocation before, as long as $p_{x}^{\prime}$ and $P_{y}^{\prime}$ satisfy no-arbitrage conditions (34) 
and (35). If these are satisfied, the economy can promptly move to the new steady-state monetary equilibrium, except during the transition period $t$ where old debtors (creditors) have a windfall gain (loss) of

$$
\frac{m^{\prime}-m}{p_{x}^{\prime}}
$$

in terms of debtor goods. Since the time- $t$ old debtors and creditors (the "initial old" following a surprise debasement) have unit elasticity of demand for young debtors' goods, first-order conditions for young debtors and creditors, and market clearing are unaffected by this reallocation.

Candidate equilibrium 2 (Time-t young debtors export). The above choices for $p_{x}^{\prime}$ and $P_{y}^{\prime}$ may not always be feasible, however. Suppose for example that in the initial equilibrium, the price of debtor goods is given by

$$
p_{x}^{*}=\frac{\phi(1-\sigma)(1-\tau)}{b}
$$

Then (34) requires that for $p_{x}^{\prime}$ as given in (48) to be feasible in the new equilibrium

$$
p_{x}^{\prime} \geq \frac{\phi\left(1-\sigma^{\prime}\right)(1-\tau)}{b^{\prime}}
$$

Hence feasibility requires that the ratio of the new price $p_{x}^{\prime}$ to the old price $p_{x}^{*}$ (weakly) exceed the ratio of the new minting point to the old, i.e., feasibility requires

$$
\frac{p_{x}^{\prime}}{p_{x}^{*}} \geq \frac{b\left(1-\sigma^{\prime}\right)}{b^{\prime}(1-\sigma)}
$$

But as incentives to recoin diminish and $m^{\prime}=\widehat{m} \rightarrow m$, then from (32)

$$
\frac{b\left(1-\sigma^{\prime}\right)}{b^{\prime}(1-\sigma)} \rightarrow \frac{\widehat{m}}{m(1-\sigma)}>\frac{\widehat{m}}{m}
$$

implying that $p_{x}^{\prime}$ given in (48) cannot be feasible.

In such cases, we can construct new equilibrium prices and a new equilibrium money stock as follows. Suppose that in the initial equilibrium, the world relative price of debtor goods exceeds the domestic relative price, i.e.,

$$
\frac{p_{x}^{*}}{P_{y}^{*}}=M R S^{*} \leq \frac{\phi}{\omega}
$$


(if this condition is violated, we must consider another new equilibrium, Candidate Equilibrium 3 below). If (55) is satisfied, choose a candidate new equilibrium debtor good price as the lowest price that will satisfy (34), i.e.,

$$
p_{x}^{\prime}=\frac{\phi\left(1-\sigma^{\prime}\right)(1-\tau)}{b^{\prime}}
$$

and choose $P_{y}^{\prime}$ and $m^{\prime}$ as

$$
\begin{aligned}
P_{y}^{\prime} & =\frac{p_{x}^{\prime}}{M R S^{*}} \\
m^{\prime} & =\frac{p_{x}^{\prime}}{p_{x}^{*}} m
\end{aligned}
$$

By construction, $p_{x}^{\prime}$ and $P_{y}^{\prime}$ satisfy (34) and (35). And, since money and prices shift proportionately, it is again straightforward to verify that there is a new steady-state monetary equilibrium with coin stock $m^{\prime}$ and prices $p_{x}^{\prime}$ and $P_{y}^{\prime}$, with the same equilibrium allocation as the old steady-state monetary equilibrium. During the transition period $t$, old debtors (creditors) will have a windfall gain (loss) given by (50), and young debtors will need to obtain $n=\left(m^{\prime}-\hat{m}\right)$ additional rixdollars. They do this by exporting

$$
\frac{\left(m^{\prime}-\hat{m}\right) b^{\prime}}{\phi\left(1-\sigma^{\prime}\right)(1-\tau)}
$$

of their endowment good to the world market. This will be feasible as long as debtors' endowments are sufficiently large. Once again, since only the period $t$ old are affected, there is no change in agents' first-order conditions or in market-clearing conditions.

Candidate equilibrium 3 (Time-t young creditors and possibly young debtors export). Suppose that candidate equilibrium 1 is not feasible but that the domestic relative price of debtor goods in the initial equilibrium exceeds the world price, i.e.,

$$
\frac{p_{x}^{*}}{P_{y}^{*}}>\frac{\phi}{\omega}
$$

Choose a candidate new equilibrium creditor good price as the lowest price that will satisfy (35), i.e.,

$$
P_{y}^{\prime}=\frac{\phi\left(1-\sigma^{\prime}\right)(1-\tau)}{b^{\prime}}
$$


and choose $p_{x}^{\prime}$ and $m^{\prime}$ as

$$
\begin{aligned}
p_{x}^{\prime} & =P_{y}^{\prime} M R S^{*} \\
m^{\prime} & =\frac{P_{y}^{\prime}}{P_{y}^{*}} m
\end{aligned}
$$

By construction, $p_{x}^{\prime}$ and $P_{y}^{\prime}$ satisfy (34) and (35). And, since money and prices shift proportionately, it is again straightforward to verify that there is a new steady-state monetary equilibrium (from $t+1$ onwards) with coin stock $m^{\prime}$ and prices $p_{x}^{\prime}$ and $P_{y}^{\prime}$, with the same equilibrium allocation as the old steady-state monetary equilibrium. However it can also be shown that these prices do not clear markets during the transition period $t$. After imposing market clearing, we can rewrite (21) for period $t$ as

$$
h\left(p_{x t}, n_{t}, \xi_{t}\right)=\frac{v_{x}\left(x-\frac{\widehat{m}}{p_{x t}}-\frac{b^{\prime} n_{t}}{\phi\left(1-\sigma^{\prime}\right)(1-\tau)}\right)}{v_{y}\left(y-c_{y}^{*}-\frac{b^{\prime} \xi_{t}}{\omega\left(1-\sigma^{\prime}\right)(1-\tau)}\right)}-\frac{b^{\prime} p_{x t}}{\omega\left(1-\sigma^{\prime}\right)(1-\tau)} \geq 0,
$$

where $c_{y}^{*}$ denotes the creditors' consumption of their endowment good under the golden-rule allocation. It is easy to show that

$$
h\left(p_{x}^{\prime}, 0, m^{\prime}-\widehat{m}\right)<0
$$

implying that time $t$ markets cannot clear for $\left(p_{x t}, P_{y t}\right)=\left(p_{x}^{\prime}, P_{y}^{\prime}\right)$. To derive market-clearing values for $p_{x t}$ and $P_{y t}$ we consider two cases:

Case 1. There exists $\widehat{p}_{x} \in\left[\frac{\phi\left(1-\sigma^{\prime}\right)(1-\tau)}{b^{\prime}}, p_{x}^{\prime}\right)$ s.t. $h\left(\widehat{p}_{x}, 0, m^{\prime}-\widehat{m}\right)=0$. Then choose $p_{x t}=\widehat{p}_{x}$ and $P_{y t}=P_{y}^{\prime}$. In this case young creditors export goods in time $t$, sufficient to mint $\xi_{t}=m^{\prime}-\widehat{m}$ new rixdollars. Time $t$ young debtors face lower prices for their endowment goods than debtors in subsequent generations.

Case 2. There is no such $\widehat{p}_{x}$ in which case from (65) and continuity of $h$ it must be case that

$$
h\left(\frac{\phi\left(1-\sigma^{\prime}\right)(1-\tau)}{b^{\prime}}, 0, m^{\prime}-\widehat{m}\right)<0
$$

But it can also be shown that

$$
h\left(\frac{\phi\left(1-\sigma^{\prime}\right)(1-\tau)}{b^{\prime}}, m^{\prime}-\widehat{m}, 0\right)>0
$$

which implies that there exists some $\widehat{n} \in\left(0, m^{\prime}-\widehat{m}\right)$ such that

$$
h\left(\frac{\phi\left(1-\sigma^{\prime}\right)(1-\tau)}{b^{\prime}}, \widehat{n}, m^{\prime}-\widehat{m}-\widehat{n}\right)=0
$$


implying that time $t$ markets will clear for $p_{x t}=\frac{\phi\left(1-\sigma^{\prime}\right)(1-\tau)}{b^{\prime}}$ and $P_{y t}=P_{y}^{\prime}$. In this case, both young creditors and young debtors export goods at time $t$ in order to coin additional rixdollars.

\subsection{Proof of Proposition 6}

(Sketch) Take $e_{r}^{\prime}=e_{r}$. The proof then exactly parallels the proof of Proposition 5 , replacing the reminting incentive condition (33) with conditions (37) and (38).

\subsection{Proof of Corollary 7}

(Sketch) In the original equilibrium, conditions (4), (5), (7), and (8) must be satisfied for coins $C$ and $R$. Rewrite these conditions as bounds on the coin weights $b_{i} / e_{i}$ for $i=\gamma, \rho$

$$
\begin{aligned}
& \frac{\phi\left(1-\sigma_{c}\right)(1-\tau)}{p_{x}} \leq \frac{b_{i}}{e_{i}} \leq \frac{\phi}{p_{x}(1-\tau)} \\
& \frac{\omega\left(1-\sigma_{c}\right)(1-\tau)}{P_{y}} \leq \frac{b_{i}}{e_{i}} \leq \frac{\omega}{P_{y}(1-\tau)}
\end{aligned}
$$

Following a transition to the new equilibrium, prices $p_{x}$ and $P_{y}$ increase by a factor of proportionality $k>1$, i.e., $p_{x}^{\prime}=k p_{x}$ and $P_{y}^{\prime}=k P_{y}$. Since $b_{r}$ and $\sigma_{r}$ do not change as a result of the debasement, then for coin $R$ to circulate at florin value $e_{r}^{\prime}$ in the new equilibrium we must have

$$
\begin{aligned}
& \frac{\phi\left(1-\sigma_{r}\right)(1-\tau)}{k p_{x}} \leq \frac{b_{r}}{e_{r}^{\prime}} \leq \frac{\phi}{k p_{x}(1-\tau)} \\
& \frac{\omega\left(1-\sigma_{r}\right)(1-\tau)}{k P_{y}} \leq \frac{b_{r}}{e_{r}^{\prime}} \leq \frac{\omega}{k P_{y}(1-\tau)}
\end{aligned}
$$

If we take $e_{r}^{\prime}=k e_{r}$,conditions (71) and (72) are identical to (69) and (70) and are clearly satisfied; the rest of the proof is straightforward. 


\section{A ppendix B: Chronology of the Bank of Ams- terdam}

- 1543: Charles V, Holy Roman Emperor, introduces the silver florin of 20 stuivers; the coin quickly disappears but the florin perists as a unit of account

- 1568: Revolt against Spain begins, widespread debasement of coinage

- 1579: Union of Utrecht, beginning of the Dutch Republic (United Provinces); coinage "standardized" but this is ineffective and debasement continues

- 1586: a new minting ordinance attempts to reset the nominal values of coins circulating in the Netherlands

- 1609: Beginning of the Twelve Years' Truce with Spain; Bank of Amsterdam (Wisselbank) founded; cashiers outlawed in Amsterdam

- 1621: Cashiers allowed again in Amsterdam

- 1622: New minting ordinance forces the Wisselbank to recognize the cross rixdollar

- 1638: Another new minting ordinance

- 1648: Treaty of Westphalia, end of Revolt

- 1659: New minting ordinance officially recognizes the distinction between the current florin and the banco florin; the agio on the banco florin reaches 5 percent

- 1672: French invasion, the Wisselbank withstands a run on its deposits; agio stabilizes between 4 and 5 percent

- 1683: The Wisselbank offers advances against gold or silver

- 1716-21: John Law's System operative in France; Wisselbank balances rapidly increase as bullion is imported into the Netherlands; balances peak at almost 29 million florins in 1721

- 1720s: The Wisselbank begins to hold significant amounts of the debt of the Dutch East India Company (VOC) 
- 1756-63: Seven Years' War; the Wisselbank "eases" the agio to 2 percent

- 1763: Financial panic; the following year balances reach an all-time high of almost 31 million florins

- 1780-84: War between the Republic and England; the Bank extends large loans to the VOC and the City of Amsterdam; agio can no longer be maintained; value of bank money falls 10 percent

- 1796-1806: Republic is dissolved; public investigation of the financial condition of the Wisselbank; advances prohibited in 1802; balances fall to 5.2 million florins by 1806

- 1806: Kingdom of the Netherlands is established

- 1814: The Kingdom of the Netherlands establishes a national central bank (De Nederlandsche Bank)

- 1820: Wisselbank liquidated 


\section{R eferences}

[1] Cipolla, C., 1956, Money, Prices, and Civilization in the Mediterranean World. Fifth to Seventeenth Century. (New York, Gordian Press).

[2] Dehing, P. and M. 't Hart, 1997, Linking the fortunes: currency and banking, 1550-1800, in M. 't Hart, J. Jonker, and J.L. van Zanden, eds., A Financial History of the Netherlands (Cambridge, Cambridge University Press) 37-63.

[3] DeVries, Jan and Ad van der Woude, 1997, The First Modern Economy: Success, Failure and Perserverance of the Dutch Economy, 1500-1815 (Cambridge, Cambridge University Press).

[4] Freeman, S., 1996, The payment system, liquidity, and rediscounting, American Economic Review 86, 1126-38.

[5] Fujiki, H., 2003. A model of the federal reserve act under the international gold standard system, Journal of Monetary Economics 50: 13331350 .

[6] Goodhart, C., 1988. The Evolution of Central Banks (Cambridge, Mass., MIT Press).

[7] Hernández-Verme, P., forthcoming, International reserves crises, monetary integration, and the payments system during the international gold standard, Macroeconomic Dynamics.

[8] Korthals Altes, W.L., 2001, De Geschiedenis van de Gulden: Van Pond Hollands tot Euro (Boom, Amsterdam).

[9] Luiten van Zanden, J., 2004, The prices of the most important consumer goods, and indices of wages and the cost of living in the western part of the Netherlands, 1450-1800. Accessed online at www.iisg.nl/hpw/data.html\#netherlands.

[10] McCusker, J. 1978, Money and Exchange in Europe and America, 16001775 (University of North Carolina Press, Chapel Hill).

[11] Posthumus, N.W., 1946, An Inquiry into the History of Prices in the Netherlands (Leiden).

[12] Rolnick, A.J., F.R. Velde, and W.E. Weber, 1996, The debasement puzzle: an essay on medieval monetary history, Journal of Economic History 56, 789-808. 
[13] Sargent, T. J. and B. D. Smith, 1997, Coinage, debasement, and Gresham's Laws, Economic Theory 10, 197-226.

[14] Sargent, T. J. and F. R. Velde, 2003, The Big Problem of Small Change (Princeton University Press, Princeton).

[15] Sargent, T. J. and N. Wallace, 1983, A model of commodity money, Journal of Monetary Economics 12, 163-187.

[16] Smith, A., [1776] 1994, The Wealth of Nations (The Modern Library, New York).

[17] Sussman, N. and J. Zeira, 2003, Commodity money inflation: theory and evidence from France 1350-1436, Journal of Monetary Economics 50, 1769-1793.

[18] Van Dillen, J.G. 1925, Bronnen tot de Geschiedenis der Wisselbanken (Rijksgeschiedkundige Publicatieën, The Hague).

[19] Van Dillen, J.G., 1934, The Bank of Amsterdam, in: J.G. van Dillen, ed.: History of the Principal Public Banks (Martinus Nijhoff, The Hague) $79-124$.

[20] Velde, F. R. and W. E. Weber, 2000, A model of bimetallism, Journal of Political Economy 108, 1210-1234.

[21] Zhou, R., 2000. Understanding intraday credit in large-value payment, Federal Reserve Bank of Chicago Economic Perspectives 24 (3): 29-44. 